\title{
The cytotoxicity of mercury chloride to the keratinocytes is associated with metallothionein expression
}

\author{
TSANN-LONG HWANG ${ }^{1,2}$, HSIAO-YING CHEN $^{3}$, TZU-TSUNG CHANGCHIEN ${ }^{3}$, \\ CHEE-CHAN WANG ${ }^{3}$ and CHI-MING WU ${ }^{3}$ \\ ${ }^{1}$ Department of Surgery, Chang Gung Memorial Hospital; ${ }^{2}$ Department of Surgery, College of Medicine, \\ Chang Gung University; ${ }^{3}$ Department of Cosmetic Science, Vanung University, Tao-Yuan, Taiwan, R.O.C.
}

Received December 19, 2012; Accepted February 5, 2013

DOI: $10.3892 /$ br.2013.65

\begin{abstract}
There are trace amounts of heavy metals in cosmetics. Heavy metals such as mercury $(\mathrm{Hg})$, which is added to skin-whitening cosmetics, may cause acute or chronic damage to human cells. The aim of this study was to investigate the cytotoxicity of mercury chloride $\left(\mathrm{HgCl}_{2}\right)$ to human keratinocytes. The keratinocytes were treated with various concentrations of $\mathrm{HgCl}_{2}$ and the cell survival fractions were found to be $38.08,17.59,12.76,3.29$ and $0.77 \%$ when the cells were treated with $0.25,0.5,0.75,1$ and $1.5 \mu \mathrm{M}$ of $\mathrm{HgCl}_{2}$, respectively. Moreover, we observed that the greatest damage was to the cell membrane. The metallothionein (MT) protein expression was also investigated. MT expression levels increased with increasing concentrations of $\mathrm{HgCl}_{2}$. The results indicated that MT protects the keratinocytes against $\mathrm{HgCl}_{2}$-induced toxicity.
\end{abstract}

\section{Introduction}

There are trace amounts of heavy metals in cosmetics. Heavy metals such as mercury $(\mathrm{Hg})$, which is added to skin-whitening cosmetics, may cause acute or chronic damage to human cells. $\mathrm{Hg}$, a divalent metal with no known biological function, may cause several deleterious effects in adults $(1,2)$, as well as in developing organisms $(3,4)$, which primarily involve the central nervous system $(5-7)$ and the kidneys $(1,8,9)$. Young animals seem to be more sensitive to $\mathrm{Hg}$ toxicity than adults, particularly during the first days following birth. $\mathrm{Hg}$ is also a widespread environmental and industrial pollutant that induces severe adverse effects in humans as well as the environment (10). Its carcinogenic activity has been welldocumented. $\mathrm{Hg}$ is also known to alter the intracellular redox

Correspondence to: Professor Chi-Ming Wu, Department of Cosmetic Science, Vanung University, 1 Van-Nung Road, Chung-Li, Tao-Yuan 32061, Taiwan, R.O.C.

E-mail: chimingwu@mail.vnu.edu.tw

Key words: cytotoxicity, mercury chloride, keratinocytes, metallothionein homeostasis $(11,12)$, which is recognized as a factor that determines cell fate (13). The outcome of cells exposed to $\mathrm{Hg}$-containing compounds depends on the chemical characteristics of the compound, as well as on its dosage, accounting for the various results reported in the literature, ranging from improved cell survival to apoptosis and necrosis.

Keratinocytes have long been considered the structural backbone of the epidermis; however, there is increasing evidence that they play an active role in the pathogenesis of skin damage by heavy metals (14). Available histopathological (15) and cytotoxicological (16-18) studies describing keratinocyte damage by mercury chloride $\left(\mathrm{HgCl}_{2}\right)$ are currently limited. This underlines the importance of investigating the direct cytotoxic effects of the metals on keratinocytes, as well as intracellular damage, for which available data are limited.

Metallothioneins (MTs) are ubiquitous, low-molecular weight proteins, rich in cysteine residues. Their high content of sulfhydrilic amino acids $(\sim 30 \%)$ gives these proteins unique metal-binding properties $(19,20)$. Factors such as exposure to toxic or essential metals $(3,21-23)$, stress $(24,25)$, radiation (26) and other agents $(27,28)$, promote the synthesis of these molecules (29). With respect to their biological functions and due to the metal affinity of their sulfhydryl groups, it is believed that MTs possess antioxidant properties $(26,30)$, are involved in the homeostasis of essential metals such as zinc ( $\mathrm{Zn})$ and copper $(\mathrm{Cu})(20,29)$ and act as detoxifying agents from metal ions $(20,31,32)$.

In this study, we investigated the cytotoxicity of $\mathrm{HgCl}_{2}$ to human keratinocytes, using human keratinocyte-derived $\mathrm{HaCaT}$ cells as an experimental model. In addition, we focused on $\mathrm{HgCl}_{2}$-induced $\mathrm{HaCaT}$ cell damage and examined the expression of MTs.

\section{Materials and methods}

Materials. Human keratinocyte-derived ( $\mathrm{HaCaT}$ ) cells were obtained from the Food Industry Research and Development Institute (Hsinchu, Taiwan). Dulbecco's modified Eagle's medium (DMEM), heat-inactivated fetal calf serum (FCS), penicillin-streptomycin solution and trypsin-EDTA solution were purchased from Life Technologies Corporation (Carlsbad, CA, USA). Sterile dimethylsulfoxide (DMSO) 3-(4,5-dimethylthiazol-2-yl)-2,5-diphenyltetrazolium bromide (MTT) and 
$\mathrm{HgCl}_{2}$ were purchased from Sigma-Aldrich (St. Louis, MO, USA).

Cell culture. HaCaT cells were grown in DMEM supplemented with heat-inactivated FCS (10\%; v/v), streptomycin (100 U/ml) and penicillin $(0.1 \mathrm{mg} / \mathrm{ml})$, in a humidified atmosphere of $5 \% \mathrm{CO}_{2}$ at $37^{\circ} \mathrm{C}$. The culture medium was changed three times a week. The cells were subcultured following trypsinization and seeded in 6 -well plate at a density of $1 \times 10^{5}$ cells per $\mathrm{cm}^{2}$.

Cells treated with $\mathrm{HgCl}_{2}$. The keratinocytes were treated with $\mathrm{HgCl}_{2}(0.25-1.5 \mu \mathrm{M})$ at $37^{\circ} \mathrm{C}$ for $24 \mathrm{~h}$. When the non-treated control cells were grown confluently, the cell groups were prepared for cell viability assay or MT western blot analysis.

MTT assay. The cell viability was monitored following treatment with various concentrations of $\mathrm{HgCl}_{2}$. MTT was used to quantify the metabolically active living cells. Mitochondrial dehydrogenases metabolize MTT to a purple formazan dye, which was measured photometrically at $570 \mathrm{~nm}$ using a spectrophotometer (33).

Western blot analysis for MT protein expression. Cell homogenates were prepared by sonication of cells in $600 \mu \mathrm{l}$ of ice-cold lysis buffer, containing $50 \mathrm{mM}$ Tris- $\mathrm{HCl}(\mathrm{pH} \mathrm{8.0)}$, $150 \mathrm{mM} \mathrm{NaCl}, 0.02 \%$ sodium azide, $100 \mu \mathrm{g} / \mathrm{ml}$ PMSF, $1 \mu \mathrm{g} / \mathrm{ml}$ aprotinin and $1 \% \mathrm{NP}-40$. Homogenates were clarified by centrifugation at $20,000 \mathrm{xg}$ for $45 \mathrm{~min}$ at $4^{\circ} \mathrm{C}$. Total protein concentration was determined using the BCA (Bio-Rad, Hercules, CA, USA) assay. Samples (50 $\mu \mathrm{g}$ of total protein) from $\mathrm{HaCaT}$ cells treated for $24 \mathrm{~h}$ with various concentrations of $\mathrm{HgCl}_{2}$ were analyzed for human MT proteins, using sodium dodecyl sulfate-polyacrylamide gel electrophoresis (SDS-PAGE; Laemmli, 1970) in 10-20\% gradient gels. Proteins were electrophoretically transferred to nitrocellulose membranes. The resulting membranes were incubated in $2.5 \%$ glutaraldehyde for $1 \mathrm{~h}$ and then washed 3 times for $5 \mathrm{~min}$ in phosphate buffer $\left(8.1 \mathrm{mM} \mathrm{Na}_{2} \mathrm{HPO}_{4}, 1.2 \mathrm{mM} \mathrm{KH}_{2} \mathrm{PO}_{4}\right.$, $2.7 \mathrm{mM} \mathrm{KCl}, \mathrm{pH}$ 7.4). Monoethanolamine $(50 \mathrm{mM})$ was added to the third wash solution to quench residual glutaraldehyde reactivity. MT proteins were detected by Immun-Star Chemiluminescent Protein Detection Systems (Bio-Rad). A monoclonal antibody to polymerized equine renal MT (Dako, Carpinteria, CA, USA) was used for immunodetection.

Statistical analysis. Means \pm standard error (SE) were calculated in triplicate. A statistical significance between the groups was determined by the Student's t-test. $\mathrm{P}<0.05$ was considered to indicate a statistically significant difference between the two groups.

\section{Results}

Cell survival fractions of $\mathrm{HaCaT}$ cells treated with $\mathrm{HgCl}_{2}$ at various concentrations. Comparison of cell survival fractions in $\mathrm{HaCaT}$ cells treated with $\mathrm{HgCl}_{2}$ at various concentrations from 0.25 to $1.5 \mu \mathrm{M}$ is shown in Fig. 1. The cell survival fraction was $38.08 \%$ when the keratinocytes were treated with $0.25 \mu \mathrm{M}$ of $\mathrm{HgCl}_{2}$. The cell survival fractions were 17.59, 12.76, 3.29 and $0.77 \%$, when the keratinocytes were treated with $0.5,0.75$,

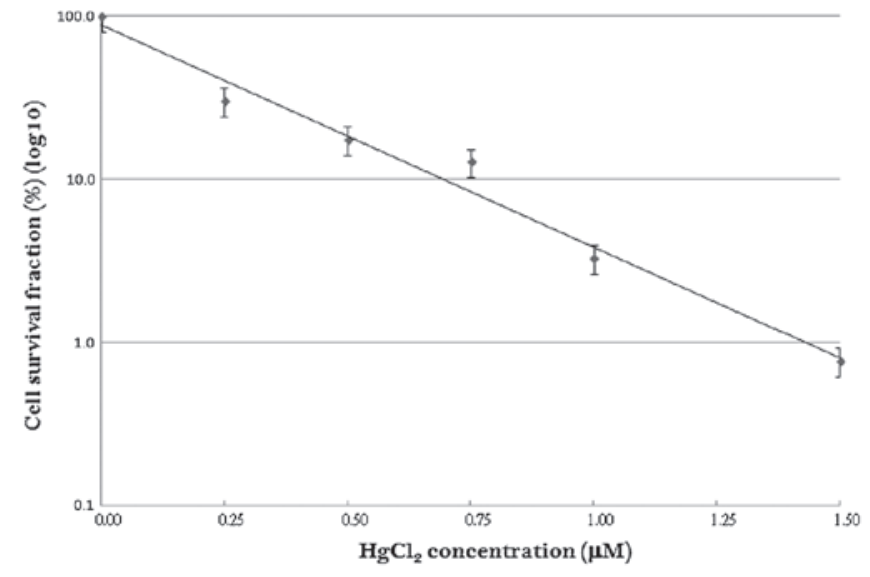

Figure 1. Cell survival fractions of $\mathrm{HaCaT}$ cells treated with $\mathrm{HgCl}_{2}$ at different concentrations. The cell survival fractions were 38.08, 17.59, 12.76, 3.29 and $0.77 \%$ when the keratinocytes were treated with $0.25,0.5,0.75,1$ and $1.5 \mu \mathrm{M}$ of $\mathrm{HgCl}_{2}$, respectively.

\section{A}

without $\mathrm{HgCl}_{2}$

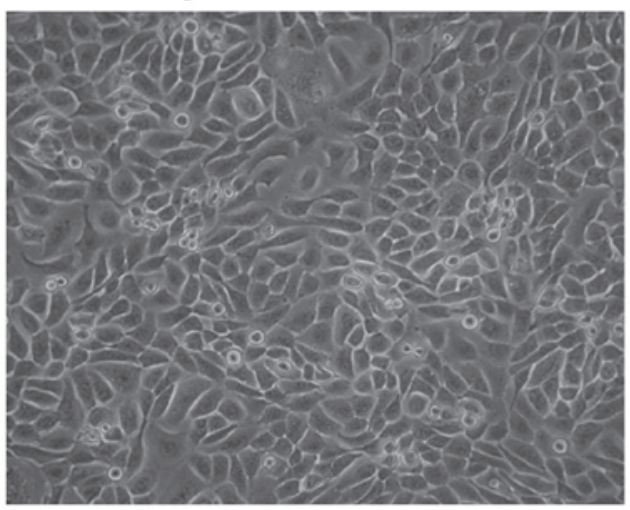

with $\mathrm{HgCl}_{2}$

B

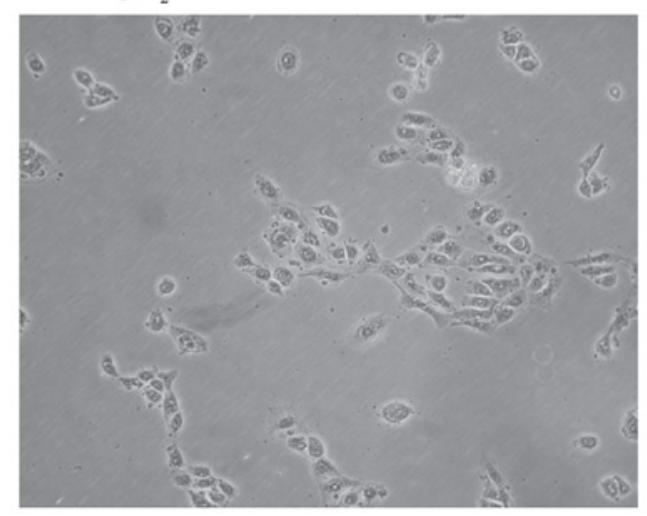

Figure 2. Morphology of HaCaT cells. (A) Control group of HaCaT cells (not treated with $\mathrm{HgCl}_{2}$ ). (B) $\mathrm{HaCaT}$ cells treated with $1.5 \mu \mathrm{M}$ of $\mathrm{HgCl}_{2}$ for $24 \mathrm{~h}$ (magnification, $\mathrm{x} 40$ ).

1 and $1.5 \mu \mathrm{M}$ of $\mathrm{HgCl}_{2}$, respectively. For each concentration investigated, a linear characteristic concentration-response curve was observed, with decreased cell survival at increasing concentrations of $\mathrm{HgCl}_{2}$ on a semi-log scale.

Effect of $\mathrm{HgCl}_{2}$ on HaCaT cell morphology. Keratinocytes were treated with $\mathrm{HgCl}_{2}$ for $24 \mathrm{~h}$ or left untreated. The $\mathrm{HaCaT}$ 
A

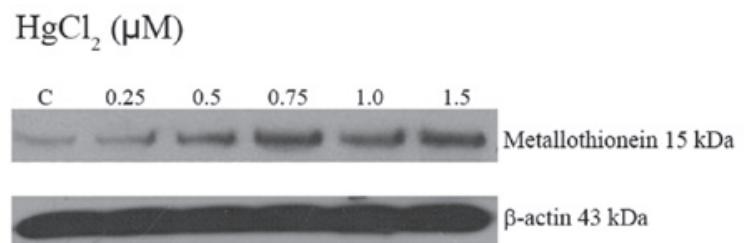

B

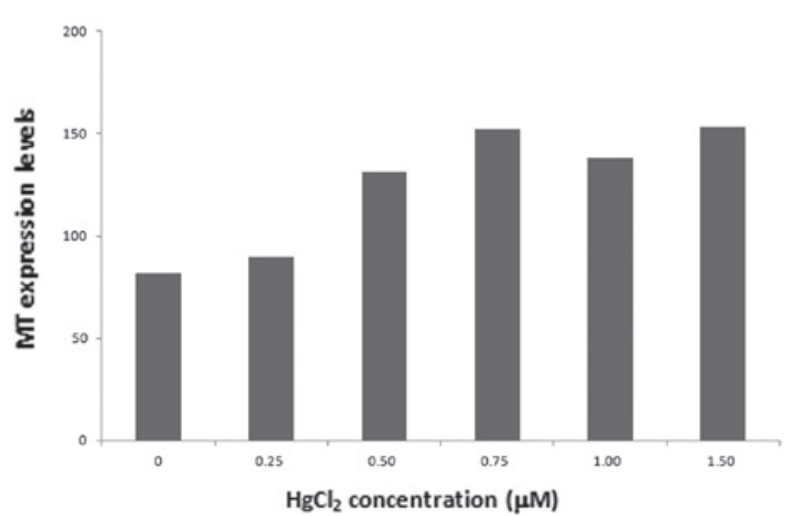

Figure 3. Metallothionein (MT) expression in $\mathrm{HaCaT}$ cells treated with $\mathrm{HgCl}_{2}$. (A) Total cellular protein $(50 \mu \mathrm{g})$ from HaCaT cells treated with $0.25-1.5 \mu \mathrm{M}$ of $\mathrm{HgCl}_{2}$ was assessed by western blot analysis for MT expression. C, untreated cells; $0.25,0.5,0.75,1.0$ and 1.5 , cells treated with $0.25,0.5$, $0.75,1.0$ and $1.5 \mu \mathrm{M}$ of $\mathrm{HgCl}_{2}$, respectively. Constitutive expression of $\beta$-actin in $\mathrm{HaCaT}$ cells demonstrated the overall protein and quality in cell lysates. (B) Quantification of the expression levels of MT in HaCaT cells treated with $0.25-1.5 \mu \mathrm{M}$ of $\mathrm{HgCl}_{2}$ and in untreated cells

cell morphology is shown in Fig. 2. The cell membrane of untreated cells is clear and intact (Fig. 2A), whereas that of $\mathrm{HgCl}_{2}$-treated cells is unclear and interrupted (Fig. 2B).

Effect of $\mathrm{HgCl}_{2}$ on MT expression. MT expression levels in $\mathrm{HaCaT}$ cells treated with various concentrations of $\mathrm{HgCl}_{2}$ are presented in Fig. 3. MT expression levels increased significantly with the increase in the concentrations of $\mathrm{HgCl}_{2}$.

\section{Discussion}

The purpose of this study was to assess the cytotoxicity of $\mathrm{HgCl}_{2}$ to the keratinocytes, as well as MT expression in $\mathrm{HgCl}_{2}$-treated keratinocytes. The results demonstrated that exposure of $\mathrm{HaCaT}$ cells to $\mathrm{HgCl}_{2}$ resulted in dose-dependent cell death and distinct cell membrane damage. Reports of $\mathrm{Hg}$ poisoning due to exposure to skin-whitening creams, ointments and soaps have increased significantly over the past few years. Furthermore, since people with lighter skin tone may represent a higher status in certain cultures, skin-whitening cosmetics are widely used by women to enhance their appeal (34-36). Otto et al (36) detected high $\mathrm{Hg}$ concentrations in the blood and urine of Balkan refugees of varying ages who had been exposed to a $\mathrm{Hg}$-based skin-bleaching ointment.

We have demonstrated that exposure of keratinocytes to $\mathrm{HgCl}_{2}$ resulted in cell membrane damage. Picoli et al (37) also investigated the effect of $\mathrm{HgCl}_{2}$ on gap junction intercellular communication (GJIC) in cultured human keratinocytes. They demonstrated that subcytotoxic concentrations of
$\mathrm{HgCl}_{2}$, as low as $10 \mathrm{nM}$, may cause inhibition of the GJIC. In addition, they demonstrated that $\mathrm{HgCl}_{2}$-treated keratinocytes exhibited a decrease in free thiols and accumulation of mitochondria-derived reactive oxygen species, albeit no effect on the respiratory chain activity was observed.

This study has demonstrated that MT expression may be induced by $\mathrm{HgCl}_{2}$ in $\mathrm{HaCaT}$ cells. Kramer et al (38) demonstrated that MT may be induced by $\mathrm{Hg}^{+2}$ in neuronal cells and induced MT decreases the rate of metal binding to other structures, providing protection against metal toxicity (39). Apart from $\mathrm{Hg}, \mathrm{MT}$ also plays a role in the homeostasis of essential metals such as $\mathrm{Zn}$ and $\mathrm{Cu}$, the detoxication of toxic metals such as Cadmium (Cd) and protection against oxidative stress (40-42). Richards et al (43) and McCormick et al (44) demonstrated that plasma zinc concentrations were related to MT expression, further suggesting an association with cellular zinc homeostasis. Ogra et al (41) demonstrated that cell viability was significantly decreased in MT-null cells compared to wild-type cells by $\mathrm{Cu}(\mathrm{I})$-specific chelator treatment (41). They also showed that MT expression levels were increased by $\mathrm{Cu}(\mathrm{I})$-specific chelator treatment in wild-type cells. Thus, MT was induced under $\mathrm{Cu}$-deficient conditions, in order to maintain the activities of intracellular cuproenzymes, such as cytochrome $c$ oxidase and $\mathrm{Cu} /$ Zinc superoxidase dismutase. Urani et al (42) showed that MT expression was upregulated following exposure to $\mathrm{CdCl}_{2}$, with a saturation curve at 48 as well as $72 \mathrm{~h}$. High levels of MT possibly confer an acquired tolerance to stress and protection against cell injury, as demonstrated by the low cytotoxicity values.

In conclusion, our results demonstrated that exposure of $\mathrm{HaCaT}$ cells to $\mathrm{HgCl}_{2}$ resulted in significant dose-dependent cell death and cell membrane damage. Moreover, MT expression may be induced by $\mathrm{HgCl}_{2}$ in $\mathrm{HaCaT}$ cells. This suggests that $\mathrm{MT}$ protects the keratinocytes against $\mathrm{HgCl}_{2}$-induced toxicity.

\section{Acknowledgements}

This study was supported by grant no. NSC 98-2314-B-238-001 from the National Science Council and grant no. VIT-98-CM-01 from Vanung University, Taiwan.

\section{References}

1. Emanuelli T, Rocha JB, Pereira ME, Porciúncula LO, Morsch VM, Martins AF and Souza DO: Effect of mercuric chloride intoxicationand dimercaprol treatment on $\delta$-aminolevulinate dehydratase from brain, liver and kidney of adult mice. Pharmacol Toxicol 79: 136-143, 1996.

2. Shigematsu J, Yasuda T, Goto Y, Tanaka K, Tobimatsu S and Kato M: Recovery of brain dysfunction after methylmercury exposure in rats. J Neurol Sci 182: 61-68, 2000.

3. Peixoto NC, Roza T, Flores EM and Pereira ME: Effects of zinc and cadmium on $\mathrm{HgCl}_{2}-\delta$-ALA-D inhibition and $\mathrm{Hg}$ levels in tissues of suckling rats. Toxicol Lett 146: 17-25, 2003.

4. Roza T, Peixoto NC, Welter A, Flores EM and Pereira ME: 2,3-Dimercapto-1-propanol does not alter the porphobilinogen synthase inhibition but decreases the mercury content in liver and kidney of suckling rats exposed to $\mathrm{HgCl}_{2}$. Basic Clin Pharmacol Toxicol 96: 302-308, 2005.

5. Pereira ME, Morsch VM, Christofari RS and Rocha JB: Methyl mercury exposure during post-natal brain growth alters behavioral response to SCH 23390 in young rats. Bull Environ Contam Toxicol 63: 256-262, 1999. 
6. Rocha JB, Rocha LK, Emanuelli T and Pereira ME: Effect of mercuric chloride and lead acetate treatment during the second stage of rapid post-natal brain growth on the behavioral response to chlorpromazine and on $\delta$-ALA-D activity in weaning rats Toxicol Lett 125: 143-150, 2001.

7. Peixoto NC, Roza T, Morsch VM and Pereira ME: Behavioral alterations induced by $\mathrm{HgCl}_{2}$ depend on the postnatal period of exposure. Int J Devl Neurosci 25: 39-46, 2007.

8. Magos L, Webb M and Butler WH: The effect of cadmium pretreatment on the nephrotoxic action and kidney uptake of mercury in male and female rats. Br J Exp Pathol 55: 589-594, 1974

9. Peixoto NC and Pereira ME: Effectiveness of $\mathrm{ZnCl}_{2}$ in protecting against nephrotoxicity induced by $\mathrm{HgCl}_{2}$ in newborn rats. Ecotoxicol Environ Saf 66: 441-446, 2007.

10. Clarkson TW and Magos L: The toxicology of mercury and its chemical compounds. Crit Rev Toxicol 36: 609-662, 2006.

11. Valko M, Morris H and Cronin MT: Metals, toxicity and oxidative stress. Curr Med Chem 12: 1161-1208, 2005.

12. Valko M, Rhodes CJ, Moncol J, Izakovic M and Mazur M: Free radicals, metals and antioxidants in oxidative stress-induced cancer. Chem Biol Interact 160: 1-40, 2006.

13. D'Autréaux B and Toledano MB: ROS as signalling molecules: mechanisms that generate specificity in ROS homeostasis. Nat Rev Mol Cell Biol 8: 813-824, 2007.

14. Luger TA, Schwarz T, Krutmann J, Kirnbauer R, Neuner P, Kock A, Urbanski A, Borth W and Schauer E: Interleukin-6 is produced by epidermal cells and plays an important role in the activation of human T-lymphocytes and natural killer cells. Ann NY Acad Sci 557: 405-414, 1989.

15. Willis CM, Stephens CJ and Wilkinson JD: Epidermal damage induced by irritants in man: a light and electron microscopic study. J Invest Dermatol 93: 695-699, 1989.

16. Picardo M, Zompetta C, De Luca C, Cristaudo A, Cannistraci C, Faggioni A and Santucci B: Nickel-keratinocyte interaction: a possible role in sensitization. Br J Dermatol 122: 729-735, 1990.

17. Little MC, Gawkrodger DJ and MacNeil S: Chromium- and nickel-induced cytotoxicity in normal and transformed human keratinocytes: an investigation of pharmacological approaches to the prevention of $\mathrm{Cr}(\mathrm{VI})$-induced cytotoxicity. Br J Dermatol 134: 199-207, 1996

18. Brosin A, Wolf V, Mattheus A and Heise H: Use of XTT-assay to assess the cytotoxicity of different surfactants and metal salts in human keratinocytes (HaCaT): Afeasible method for in vitro testing of skin irritants. Acta Derm Venereol 77: 26-28, 1997

19. Chan J, Huang Z, Merrifield ME, Salgado MT and Stillman MJ: Studies of metal binding reactions in metallothioneins by spectroscopic, molecular biology, and molecular modelling techniques. Coord Chem Rev 233-234: 319-339, 2002.

20. Dabrio M, Rodríguez AR, Bordin G, Bebianno MJ, De Ley M Sestáková I, Vasák M and Nordberg M: Recent developments in quantification methods for metallothionein. J Inorg Biochem 88: 123-134, 2002

21. Goering PL and Fowler BA: Metal constitution of metallothionein influences inhibition of $\delta$-aminolaevulinic acid dehydratase (porphobilinogen synthase) by lead. Biochem J 245: 339-345, 1987

22. Pedersen SN, Pedersen KL, Hojrup P, Knudsen J and Depledge MH: Induction and identification of cadmium-, zinc- and copper-metallothioneins in the shore crab Carcinus maenas (L.) Comp Biochem Physiol C Pharmacol Toxicol Endocrinol 120: 251-259, 1998

23. Bebianno MJ and Langston WJ: Metallothionein induction in mussels exposed to a metal mixture. In: Metallothionein IV (Advances in Life Sciences). Klaassen CD (ed). Birkhäuser Verlag Basel, Switzerland, pp187-194, 2009.

24. Kondoh M, Tsukahara R, Kuronaga M, Higashimoto M, Takiguchi M and Sato M: Enhancement of MT synthesis by leptin in fasted mice. Life Sci 71: 2425-2433, 2002.
25. Kondoh M, Kamada K, Kuronaga M, Higashimoto M, Takiguchi M, Watanabe Y and Sato M: Antioxidant property of metallothionein in fasted mice. Toxicol Lett 143: 301-306, 2003.

26. Cai L, Satoh M, Tohyama C and Cherian MG: Metallothionein in radiation exposure: its induction and protective role. Toxicology 132: 85-98, 1999.

27. Rojas P, Cerutis DR, Happe HK, Murrin LC, Hao R, Pfeiffer RF and Ebadi M: 6-Hydroxydopamine-mediated induction of rat brain metallothionein I mRNA. Neurotoxicology 17: 323-334, 1996.

28. Theocharis SE, Margeli AP, Skaltsas SD, Spiliopoulou CA and Koutselinis AS: Induction of metallothionein in the liver of carbon tetrachloride intoxicated rats: an immunohistochemical study. Toxicology 161: 129-138, 2001.

29. Dunn MA, Blalock TL and Cousins RJ: Metallothionein. Proc Soc Exp Biol Med 185: 107-119, 1987.

30. Cai L and Cherian MG: Zinc-metallothionein protects from DNA damage induced by radiation better than glutathione and copperor cadmium-metallothioneins. Toxicol Lett 136: 193-198, 2003.

31. Stillman MJ: Metallothioneins. Coord Chem Rev 144: 461-511, 1995.

32. Yoshida M, Satoh M, Shimada A, Yasutake A, Sumi Y and Tohyama C: Pulmonary toxicity caused by acute exposure to mercury vapor is enhanced in metallothionein-null mice. Life Sci 64: 1861-1867, 1999.

33. Green LM, Reade JL and Ware CF: Rapid colorimetric assay for cell viability: application to the quantitation of cytotoxic and growth inhibitory lymphokines. J Immunol Methods 70: 257-268, 1984

34. Jovanovic S, Maisner V, Horras-Hun G, Gabrio T and Schwenk M: Poisoning of a family by a mercury-containing ointment. Gesundheitswesen 59: 405-408, 1997 (In German).

35. Weldon MM, Smolinski MS, Maroufi A, Hasty BW, Gilliss DL, Boulanger LL, Balluz LS and Dutton RJ: Mercury poisoning associated with a Mexican beauty cream. West J Med 173: 15-18, 2000.

36. Otto $\mathrm{M}$, Ahlemeyer $\mathrm{C}$, Tasche $\mathrm{H}$ and von Mehlendahl KE: Endemic mercury burden caused by a bleaching ointment in Balkan refugees. Gesundheitswesen 56: 686-689, 1994 (In German).

37. Piccoli C, D'Aprile A, Scrima R, Ambrosi L, Zefferino R and Capitanio N: Subcytoxic mercury chloride inhibits gap junction intercellular communication by a redox- and phosphorylation-mediated mechanism. Free Radical Bio Med 52: 916-927, 2012.

38. Kramer KK, Zoelle JT and Klaassen CD: Induction of metallothionein mRNA and protein in primary murine neuron cultures. Toxicol Appl Pharmacol 141: 1-7, 1996.

39. Cherian MG and Nordberg M: Cellular adaptation in metal toxicology and metallothionein. Toxicology 28: 1-15, 1983.

40. Davis SR and Cousins RJ: Metallothionein expression in animals: a physiological perspective on function. J Nutr 130: 1085-1088, 2000.

41. Ogra Y, Aoyama M and Suzuki KT: Protective role of metallothionein against copper depletion. Arch Biochem Biophys 451: 112-118, 2006.

42. Urani CM, Melchioretto P, Canevali C, Morazzoni F and Gribaldo L: Metallothionein and hsp70 expression in HepG2 cells after prolonged cadmium exposure. Toxicol In Vitro 21: 314-319, 2007.

43. Richards MP and Cousins RJ: Mammalian zinc homeostasis: requirement for RNA and metallothionein synthesis. Biochem Biophys Res Commun 64: 1215-1223, 1975.

44. McCormick CC, Menard MP and Cousins RJ: Induction of hepatic metallothionein by feeding zinc to rats of depleted zinc status. Am J Physiol 240: E414-E421, 1981. 